\title{
THE MEDIEVAL LEGAL PRACTICE OF EXCULPATORY OATH \\ AND TRIAL BY FIRE IN THE LEGEND OF QUEEN ISOLDE*
}

\author{
AlicJa BańCZYK \\ Uniwersytet Jagelloński w Krakowie
}

\section{Introduction}

This paper, making a use of methods worked over by the law and literature studies will analyse one of the episodes of the legend of Tristan and Isolde, in which queen Isolde render the exculpatory oath with regard to the charge of adultery and is subject to the trial by fire. The research is utmost conducted in order to answer the question, whether the literary presentations of this scene reflect the proper legal practice of ordeal in Medieval France.

This analysis is also supposed to facilitate better understanding of the institution of medieval ordeals which is difficult for modern readers as it does not exist in contemporary legal systems. Finally, this analysis can also help understand the motivations of protagonists and their behaviour towards this kind of judgement and therefore it can help better interpret the meaning of this episode to the development of the plot.

\section{Tristan and Isolde legend}

It seems to be superfluous to repeat in this article the whole legend about the golden hair queen Isolde being, due to some unfortunate events, in love with Tristan, who is revealed to be the nephew of her own husband, king Mark. The reason for that is the fact that this story seems to be deeply grounded in the European culture and it even entered popular culture due to its adaptations to the big screen ${ }^{1}$. Moreover, it seems very difficult to reconstitute the only correct and coherent version of this legend because up till now there are

\footnotetext{
* The present article develops my previous research conducted on this subject; it focuses however on the legal aspect of the trial.

1 It is enough to mention the very popular Kevin Reynolds' film entitled Tristan and Isolde from 2006 or the Italian Fabrizio Costa's film Il cuore e la spada released in 1998. There is even a cartoon French version of the legend, popularising this medieval legend among the youngest and we can also find some book adaptations for young adults and children.
} 
numerous variants of it preserved and every one of them seems to add some new elements to this very old literary tradition, contributing to the production of the whole Tristan and Isolde story cycle ${ }^{2}$.

There are several medieval texts of this legend preserved in different languages. Two oldest versions are in ancient French. The first one is written by a man called by himself Béroul and it originates from between 1150 and 1200 . The second one is written around 1170 by someone traditionally named Thomas of England. Unfortunately, both versions are not complete and the analysed episode does not appear in any of the preserved manuscripts of Thomas' work. We can however to a great extent reconstruct its contents based on later texts deriving from Thomas's version, namely the text by Gottfried von Strassburg from around 1210 and text of brother Robert entitled Saga of Tristan created around 1226 on the court of king Hakon of Norway, which is supposed to be, according to the research conducted on this subject, an accurate translation of Thomas's work.

The present analysis will be based mostly on the version of Béroul and on the Saga of Brother Robert. However, some connections with the most famous reminiscence on prose of the legend, which in fact is the attempt of the compilation of all the versions written in 1900 by a famous French medievalist Joseph Bédier will be made.

\section{History of the institution of ordeal}

The analysis of the exculpatory oath of Isolde and the trial by fire on her should be with no doubts begun by the presentation of the medieval legal institution of the ordeal. This task can be however very difficult as this institution is for us very mysterious and we don't even know it's origins. Some ordeals are believed to be already presented in the Ancient Testament ${ }^{3}$ and in some other texts providing form Antiquity, however, in European cultural circle we tend to identify their application with the Middle Ages and the popularisation of the Christianity ${ }^{4}$.

If it goes to the nature of the trial by ordeal, according to Rebecca V. Colman «[o]rdeals were ceremonially administrated physical tests used as a

2 We can for example recall a very short story written by famous medieval author Marie de France, called Chevrefoil (eng. The Honeysuckle) where the author presents her own vison of only one episode of this story where Tristan meets Isolde in the forest.

3 VAN DER TOORN (1988), p. 427.

4 RESZYŃski (2010), pp. 196-197. 
form of proof $»^{5}$ and «their outcomes were interpreted as manifestations of divine judgment $»^{6}$. They functioned therefore as tests calling for help of the divinity. Those tests normally consist on application of different kind of unpleasant and difficult experiments used onto the parties in dispute or the accused in the penal procedure, the results of which implied the judgment and penalisation. P. Brown notes that the result of this kind of trial was an upshot of different proofs: «The effect of a hot iron on the hand that could hold it for nine paces, of boiling water on the arm that had snatched and object from a cauldron, of whether a man sank (if innocent) or floated (if guilty) in a pool of water, the result of duel» ${ }^{7}$.

Knowing the essence of this institution we can easily understand that ordeals were used only if other evidentiary methods failed and if there was no other way to prove the truth demanded by many of medieval legal systems (for example Lex Salica demanded a 'certain proof') ${ }^{8}$. Trial by ordeal was therefore used when the evidence was either unavailable (like in cases of doubted fatherhood, unsolvable without DNA tests an so as above the competences of the human judges), or when in the particular case it was forbidden for the party to swear an oath (for example when he or her had been already sentenced for perjury) ${ }^{9}$. In those cases the only way to know what was the truth was to ask a divinity to solve the problem as gods can see things impossible to notice for the human reason.

The first evidence of application of the ordeals in Western Europe come from years 800-1200 (what doesn't exclude their usage before any source about them was written), while their 'golden era' is traditionally dated at $11^{\text {th }}$ and $12^{\text {thio }}$. It is also undeniable that the year 1215 constitute the twilight of ordeal's era. It was then when the legislation of Council of Lateran IV banned the clergy's involvement in conduct of the ordeals and this decision deprived ordeals of their sacral content by denying that God is present during this kind of trial ${ }^{11}$. As the institution was forbidden by the Church and as priests were no longer present during those trials, people were less willing to participate in it. Moreover, church propaganda began presenting trial by ordeal as a pagan

\footnotetext{
5 Colman (1974), p. 582.

6 Colman (1974), p. 582.

7 BRown (1975), p. 135.

8 Colman (1974), p. 578.

9 Lemesle (2016), p. 17.

10 Bartlett (1988), p. 13.

11 McAuley (2006), p. 473.
} 
superstition as in the case of ordeal the "passage between the sacred and the profane» was from the beginning very easy, as notes P. Brown ${ }^{12}$.

In this place, it should be noted that the majority of preserved version of the legend on Tristan and Isolde derive from the undeniable fall of the époque of ordeals, so they rather recall the custom less and less used which could however still be connected with the times gone, in which the plot is placed. Therefore the introduction of this passage can be considered as an element or archaization of the story. It must also be added that the acceptation of the commonly agreed concept that the legend of Tristan and Isolde has Celtic roots $^{13}$ leads to the conclusion that the episode itself is younger than the original version of the legend and maybe this element derives from the times of its writing down the oral transmission.

\section{The trial of Isolde from the literary perspective}

The analysed episode, namely the scene of the exculpatory oath and trial by fire differs between varied versions of the legend of Isolde. It begins unequivocally from convening the gossips spreading around on the court of King Marke about the indecent relation linking his beautiful young wife and his brave nephew. King, either asking for advice of his counselors (Saga), or with persuasion of unfriendly informers (Béroul), wants to get to know the truth from the queen. Isolde defends herself against all those accusations and declares to be ready to swear an exculpatory oath (Béroul) and proposes even to be tested by some kind of ordeal (other versions). At the same time, she informs Tristan and asks him to wait for her, dressed anonymously, on the road, which she would go onto the place of her swearing. Getting to this place, queen says that she is unable to walk through the marsh without having her expensive clothes dirty. Support is offered by Tristan dressed like a lepper Welsh (Béroul's text) or pilgrim (other versions). He takes her on his back (Béroul), or his arms (other), through the marsh. Then the queen arrives to the place of her swearing and swears an unequivocal oath, that no man besides king Mark, her husband, and the lepper who «like a carrying saddlebags animal» took her onto the other side of the marsh was between her thighs (Béroul), or, in less literal versions, the queen swears that no one besides those two had her in his arms (other).

12 BRown (1975), p. 135.

13 Tristan i Izolda, p. XXXV. 
In Béroul's version this episode ends in this place with unheard by the public declaration of the queen that she can be tested otherwise. In other versions (so probably alike as in the Thomas' version), after the oath there came the trial by fire (hot iron trial), after which the queen reaches the success and regains the trust of her husband.

\section{Isolde's trial from the perspective of medieval legal practice}

Searching for the answer on the question, to which extent the literary text reflect the historical truth, at first it must be observed that ordeals were in the Middle Ages often used with regard to women accused of breach of purity, or betrayal. In such circumstances they were used by king Lotar, who wanted to get rid of his wife Teutberg and accused her of sodomy and incest. So did Carolingian king Charles the Fat, whose wife in 887 was tested in trial by fire (hot plowshare), being accused of betrayal. Those examples could have been models of proceeding with unfaithful wives in the Middle Ages so the authors of medieval texts could have used those examples while inventing the plots of their works ${ }^{14}$.

Traditionally, we divide Medieval ordeal with regard to the number of participants onto two-sided (for example combat) and one-sided (trial by cold water, by hot water, by fire, etc. ${ }^{15}$. The question why Isolde was tested with this particular kind of ordeal (trial by fire) seems to be very interesting. Probably the reason for this was her general situation. As a woman she was obviously unable to participate in any combat and on the land of King Marke there was no relative of her, who could have done it for her. She was conscious of it and in Béroul's text she claims, that she has no relative, who could start a war for her ${ }^{16}$. This fragment can be understood as a direct connotation to ordeal in form of an encounter.

As Isolde cannot fight to prove her right, in all the texts on the ordeals she is tested by the trial by fire and she does some steps hanging hot iron in her hand. Analysing later English versions of the legend, Ernest C. York points out that this kind of ordeal was frequently used on people of high rank as in

14 Lemesle (2016), p. 16.

15 Dziadzio (2008), p. 423.

16 It is important to rembember that trial by combat was the most popular one in the French medieval literature and we can find a lot of examples of it for example in epic poems (chansons de geste). 
ancient texts «the association of the hot iron ordeal with aristocratic groups is noted quite early ${ }^{17}$. Therefore the trial by fire could have been used as Isolde was the king's wife. On the other hand, according to the historical sources providing from the Middle Ages more than half of ordeal conducted in the Middle Ages were trials by fire, namely connected with contact of the tested person with the incandescent objects (like horseshoes) ${ }^{18}$ so maybe the author of the text simply used the kind of ordeal he knew the best and he considered the most popular.

The medieval legal practice is also reflected in the excerpts of the texts depicting the preparatory ceremonies, namely listening to the holy mas by the queen, giving alms (Saga) or simply praying before the trial (other). Medieval descriptions of the ordeals keep repeating that before the ordeal a mass should be done and prayers made ${ }^{19}$. They were without any doubt the proof of the good will of the person accused and it demonstrated his or her intention to rely on the will of God and on his judgement.

Even if there are a lot of similarities between texts of the legend and the medieval legal practice we can still find some differences between the real ordeal practice and the way how it was presented in analysed texts.

The difference, which is done immediately after such comparison is that queen Isolde left the test untouched and after crossing the prescribed number of steps (possibly nine feet as it was the traditional distance), holding hot iron, she showed to the public her entirely sound hands. However, the procedural practice did not demand that the person tested by ordeal suffered no injury. The whole procedure was based on the observation, how the wound gets better and whether the process of healing is undisturbed by infections and contagions, which could have been a sign that God does not protect such a person. This is why, after the trial, the hand of the tested person was bandaged and sealed for three days and after that was shown to the judges, who assessed, that the God (and truth) are on the side of the accused ${ }^{20}$.

The fact that Isolde left the trial entirely untouched means that the authors of the text wanted to prescribe to God even greater function than the one demanded by law. The trial by fire on Isolde seems to be some kind of miracle and this is how it was probably understood by the medieval audience.

\footnotetext{
17 York (1971), p. 7.

18 Lemesle (2016), p. 19.

19 Lemesle (2016), p. 19.

20 Ho (2003-2004), p. 261.
} 
It is also interesting that in all versions of the legend of Tristan and Isolde analysed in this article it is Isolde herself (more or less forced thereto by the circumstances) offers swearing an exculpatory oath. Also when ordeal are concerned, the initiative is also hers. According to R. Bartlett, it was very common in the Middle Ages that the accused persons treated ordeals as the last means to save their position, when all other means were against them. R. Barlett also states that people offered to be subject to such a trial only to manifest the sincerity of theirs statements. This is why offers like this were often made in political processes ${ }^{21}$. Nobody truly expected that the trial will be actually done and it was rather awaited that the other side of the dispute would feel mercy and resign from putting the other subject to this very cruel kind of trial.

This is why the fact that Isolde claimed her readiness to be subject to trial by fire or «any other mean to render her innocence» does not have to mean that she really wanted those proceedings to be done. Maybe she expected that her husband would feel mercy and allow that no pain is suffered by his own wife. The evidence onto such a statements is an excerpt from Béroul's version, in which Isolde declared her readiness to be subject to the ordeal with words «If anyone wants me to anything more, I am ready» ${ }^{22}$. This declaration however remains unanswered and no ordeal is proceeded. Then we can reach the conclusion that those versions which depict the trial by fire show king Mark in a very negative perspective, making him a cruel person, ready to seriously injury his own wife. Moreover, we should note that this trace of king Mark character is also presented in English versions of the legend ${ }^{23}$ so it was rather this trace of king's character which preserved in later versions.

The last interesting issue, which demands a vaguer analysis is the contents of the oath sworn by Isolde. It is a very famous literary example of ambiguous oath which is at first true, but in fact it is a caricature of the actuality. It is true that nobody else besides the king and the passer-by was between queen's thighs. It is also true that Tristan was the passer-by. Then it is true that queen had a sexual relation with the stranger and the whole proceeding was to proof the opposite. Then the scene even for the modern reader seems to be comedian, yet in the Middle Ages in must have been a contempt for the trial, in

21 Bartlett (1988), p. 15.

22 This is also the interpretation of this fragment given by GorecKa-KaLita (2006), p. 101.

23 Cf. York (1971). 
which the judge was the God himself. Isolde wants to cheat on God, put him on the test and therefore she committed a sin.

B. Lemesle interprets this fragment stating that this kind of unequivocal oaths were often presented in literary works from $12^{\text {th }}$ and $13^{\text {th }}$ centuries as a result of the general crisis of the institution of ordeal ${ }^{24}$. According to P. Brown such presentations of the institution of the ordeal as in Tristan and Isolde story were «a tiny outcrop of the vast bedrock of cunning with which medieval men actually faced and manipulated the supernatural in their affairs $»^{25}$. We should agree with those two scholars that this fragment can show us how people of late 12th century were losing confidence in this kind of proceeding. It can be also added that this fragment could have been an element introduced by the writer, who was probably a religious person, to popularise the Church propaganda of this time, by ridiculing the ambiguous practice of ordeal and therefore by making a folk superstition of it.

\section{Conclusion}

Coming to the conclusion of this literary episode of the exculpatory oath of Isolde and the trial by fire on her from the perspective of law and literature may lead to very interesting conclusions. The research shows that the scene reflects a big dose of historical truth with regard to the practice of ordeals in the Middle Ages, but also certain exceptions to this. As a result, this kind of analysis could be of great value to the historians of literature. They allow to see the variances, which the traditional literary analysis will omit, which at the longer perspective could allow to ask questions about the reasons thereto and then the meaning of the analysed scene to the entire work. It also helps position the excerpt in broader historical context and accept it as an interesting evidence of the attitude of people of the Middle Ages to the practice of the ordeal, which already then have ceased to be a way to prove the truth because as states H. L. Ho «in the practices of the ordeals faith mingled with superstition, justice with mercy, divine providence with human manipulation ${ }^{26}$.

24 Lemesle (2016), p. 6.

25 Brown (1975), p. 139.

26 Ho (2003-2004), p. 259. 


\section{Bibliography}

Bartlett, R. (1988): Trial by Fire and Water. The Medieval Judical Ordeal, New Jork;

Brown, P. (1975): "Society and the Supernatural: A Medieval Change”, Daedalus, 104, pp. 133-151;

Colman, R. V. (1974): "Reason and UNreason in Early Medieval Law”, The Journal of Interdisciplinary History, 4/4, pp. 571-591;

Dziadzio, A. (2008): Powszechna historia prawa, Warszawa;

Gorecka-Kalita, J. (2006): Tristan i Izolda, Wrocław-Warszawa-Kraków;

Ho, H. L. (2003-2004): “The Legitimacy of Medieval Proof”, Journal of Law and Religion, 19/2, pp. 259-98;

LEmesle, B. (2016): La main sur le fer rouge. Le jugement de Dieu au Moyen Age, Dijon;

McAuley, F. (2006): "Canon Law and the End of the Ordeal", Oxford Journal of Legal Studies, 26/3; pp. 473-513;

RESzYŃski, J. (2010): "Czarownica pławiona i spalona w mieście Delhi w 1340 roku, czyli o powszechnikach kulturowych i ich roli w prawie karnym”, Krakowskie Studia z Historii Państwa i Prawa, 3, pp. 196-197;

VAn Der Toorn, K. (1988): "Ordeal Procedures in the Psalms and the Passover Meal”, Vetus Testamentum, 38/4, pp. 427-445;

York, E. C. (1971): "Isolt's Ordeal: English Legal Customs in the Medieval Tristan Legend”, Studies in Philology, 68/1, pp. 1-9. 
Historia del derecho, 73

ISSN: 2255-5137

(C) 2019 Autores

Motivo de cubirta:

Carlo Coppola, Il Tribunale della Vicaria

XVII secolo, olio su tela, Napoli, Museo di San Martino

Per gentile concessione del Ministero per i beni e le attività culturali

Polo Museale della Campania

Editorial Dykinson

c/ Meléndez Valdés, 61 - 28015 Madrid

Tlf. (+34) 915442846

E-mail: info@dykinson.com

http://www.dykinson.com

Preimpresión: TALLERONCE

ISBN: 978-84-1324-239-2

Depósito Legal: M-21371-2019

Versión electrónica disponible en e-Archivo

http://hdl.handle.net/10016/28459

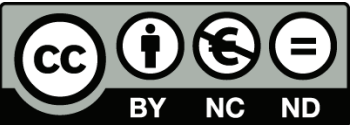

Licencia Creative Commons Atribución-NoComercial-SinDerivadas 3.o España 